\title{
Phytophthora shoot rot - new disease of Mandevilla sanderi in Poland
}

\section{Fytoftoroza - nowa choroba Mandevilla sanderi w Polsce}

\author{
Leszek B. Orlikowski*, Magdalena Ptaszek
}

\begin{abstract}
Summary
Chlorosis of leaves, their necrosis and development of stem base rot were observed on about $7 \%$ of dipladenia grown in greenhouse conditions. Necrosis observed on the stem base of such plants spread upward and on the root system. Phytophthora niederhauserii was isolated from all analyzed, diseased plants as well as from substratum. In addition Botrytis cinerea, Fusarium avenaceum and $F$. solani were sporadically isolated from diseased plants as well. On dipladenia organs inoculated with $P$. niederhauserii necrosis spread about $6-8 \mathrm{~mm} / 24 \mathrm{hrs}$. The obtained results are the first information reporting the occurrence of $P$. niederhauserii on dipladenia in Poland.
\end{abstract}

Key words: dipladenia; Phytophthora niederhauserii; symptoms; pathogenicity

\section{Streszczenie}

W uprawie szklarniowej dipladenii na około 7\% roślin stwierdzono chlorozę liści, zgniliznę ogonków i blaszek liściowych, więd nięcie i stopniowe ich zamieranie. U nasady łodyg takich roślin występowała zgnilizna, rozszerzająca się ku górze oraz w kierunku korzeni. Ze wszystkich porażonych roślin będących przedmiotem badań oraz z podłoża izolowano głównie Phytophthora niederhauserii i sporadycznie Botrytis cinerea, Fusarium avenaceum i F. solani. Na zainokulowanych przez $P$. niederhauserii organach dipladenii nekroza rozwijała się około 6-8 $\mathrm{mm}$ na dobę. Uzyskane wyniki są pierwszymi danymi o występowaniu $P$. niederhauserii na dipladenii w Polsce.

Słowa kluczowe: dipladenia; Phytophthora niederhauserii; objawy chorobowe; patogeniczność

Instytut Ogrodnictwa

Konstytucji 3 Maja 1/3, 96-100 Skierniewice

*corresponding author: leszek.orlikowski@inhort.pl 


\section{Wstęp / Introduction}

Mandevilla sanderi (= Dipladenia sanderi) znana pod nazwą dipladenia jest cenioną rośliną doniczkową uprawianą w kraju pod osłonami. Roślina należy do rodziny Apocynaceae i występuje naturalnie w Ameryce środkowej i południowej. Dane z piśmiennictwa wskazują, że jakość produkowanych roślin może być drastycznie obniżana lub często dochodzi do ich masowego wypadania wskutek pojawiających się chorób. Paludan i wsp. (1988) stwierdzili na liściach tej rośliny wirusa mozaiki tytoniu i nazwali go mozaiką wirusową dipladenii. Ruhl i wsp. (2011) na ukorzenianych sadzonkach dipladenii opisali bakteryjną zgniliznę, której przyczyną okazał się gatunek Ralstonia solanacearum. Eltibany i wsp. (2012) na liściach dipladenii obserwowali rozległe, nekrotyczne plamy z szeroką, żółtawą obwódką, a sprawcą choroby okazała się bakteria Pseudomonas savastanoi. $\mathrm{Na}$ roślinach matecznych dipladenii Sella i wsp. (2010) stwierdzili żółknięcie i zamieranie liści, powodowane przez Fusarium oxysporum.

W 2014 roku na dipladenii w uprawie szklarniowej, w stadium pąków i początku kwitnienia obserwowano objawy więdnięcia i stopniowego zamierania roślin.

Celem badań było określenie przyczyny choroby prowadzącej do znacznych strat w uprawie dipladenii.

\section{Materiały i metody / Materials and methods}

Porażony materiał roślinny. Wiosną 2014 roku w uprawie szklarniowej dipladenii w stadium dobrze wykształconych pąków kwiatowych i pierwszych, rozwijających się kwiatów stwierdzono na około $7 \%$ roślin występowanie zróżnicowanych objawów chorobowych. Jasnozielone lub żółtawe dolne liście niektórych roślin więdły i zwisały na łodygach. Na części roślin, na dolnych liściach wystąpiła zgnilizna ogonków liściowych rozszerzająca się klinowato aż do połowy powierzchni blaszek. W następstwie tych objawów liście zwisały na łodygach. Przy poruszeniu roślin liście opadały na podłoże. Analiza łodyg wykazała występowanie brunatnej nekrozy u ich nasady, rozszerzającej się ku górze i w kierunku korzeni. Na większości pędów zgnilizna występowała na całym obwodzie, na odcinku od około $15 \mathrm{~mm}$ do nawet $50 \mathrm{~mm}$. Końcowym etapem rozwoju choroby było zżółknięcie lub/i zbrunatnienie części liści i stopniowe zamieranie dipladenii.

Analiza mikologiczna chorych roślin i podłoża. W celu stwierdzenia przyczyny choroby, trzykrotnie, w odstępach tygodniowych pobierano ze szklarni po 15 chorych roślin i transportowano je do laboratorium. Po usunięciu zbrunatniałych i opadłych liści, $\mathrm{z}$ każdej rośliny preparowano około 7-centymetrowej długości części łodyg i po 4 liście $\mathrm{z}$ objawami nekrozy u ich nasady. Rośliny płukano wodą wodociągową, a następnie destylowaną i po osuszeniu między warstwami sterylnej bibuły filtracyjnej i odkażeniu nad płomieniem palnika, pobierano około $5 \mathrm{~mm}$ fragmenty, które wykładano do szalek Petriego z pożywką ziemniaczano-glukozową (PDA - Potato Dextrose Agar). Po 48 godzinach inkubacji w ciemności, w temperaturze $25^{\circ} \mathrm{C}$ fragmenty strzępek wyrastające $\mathrm{z}$ inokulów przeszczepiano na skosy z pożywką PDA. Procedurę dalszego postępowania oparto na metodyce podanej przez Orlikowskiego i Szkutę (2001). Ponadto określano występowanie Phytophthtora sp. w podłożu stosując metodę pułapkową z liści różanecznika (Orlikowski i wsp. 2011). Wybrane kultury reprezentacyjne uzyskane $\mathrm{z}$ materiału roślinnego i podłoża oznaczano do rodzaju i gatunku na podstawie ich cech morfologicznych. W celu potwierdzenia uzyskanych wyników, DNA kultur amplifikowano w reakcji PCR (polymerase chain reaction) z wykorzystaniem starterów ITS6 (Cooke i wsp. 2000) i ITS4 (White i wsp. 1990), a następnie sekwencjonowano region ITS1-5.8S-ITS2 rDNA. Uzyskane odczyty porównano z sekwencjami zdeponowanymi w bazie danych GenBank.

Ocena chorobotwórczości. Izolat D1 badanego gatunku wybrano losowo spośród kilkudziesięciu innych kultur i inkubowano go na pożywce PDA przez 7 dni w temperaturze $25^{\circ} \mathrm{C}$. Następnie krążkami pożywki o średnicy $5 \mathrm{~mm}$, przerośniętymi strzępkami patogena, inokulowano nasady ogonków liściowych, części korzeni i łodyg oraz nanoszono je na środek blaszek liściowych umieszczonych w kuwetach wyłożonych 2 warstwami wilgotnej, sterylnej bibuły przykrytej cienką, nylonową siatką. Kuwety okrywano szczelnie folią i ustawiano na stołach laboratoryjnych $\mathrm{w}$ temperaturze $22-24^{\circ} \mathrm{C}$. Pomiary długości i średnicy nekrotycznych plam wykonano po 3 i 5 dniach inkubacji.

W doświadczeniu szklarniowym krążki pożywki ze strzępkami Phytophthora sp. umieszczano w miejscach rozgałęzień pędów dipladenii, po czym zainokulowane rośliny umieszczano pod tunelem z folii. Po 4 i 6 dniach inkubacji w temperaturze wahającej się od 17 do $24^{\circ} \mathrm{C}$, mierzono długość nekrozy na pędach i ogonkach liściowych.

Doświadczenia założono w układzie kompletnie losowym w 4 powtórzeniach po 5 części lub fragmentów organów dipladenii w warunkach laboratoryjnych i w układzie bloków losowych w szklarni w 4 powtórzeniach po 5 roślin. Każdą z roślin inokulowano w 4 miejscach. Doświadczenia powtórzono 2-krotnie w odstępie 2 tygodni.

\section{Wyniki i dyskusja / Results and discussion}

Phytophthora niederhauserii izolowano ze wszystkich dipladenii wykazujących objawy zmiany zabarwienia liści, ich więdnięcia, nekrozy ogonków i blaszek liściowych oraz zgnilizny części łodyg. Gatunek stwierdzono również we wszystkich analizowanych próbach podłoża spod chorych roślin. Obok tego gatunku sporadycznie stwierdzano występowanie Botrytis cinerea, Fusarium avenaceum i $F$. solani.

Inokulacja części korzeni i łodyg dipladenii izolatem $P$. niederhauserii powodowała szybką kolonizacją tkanek. Już po 3 dniach inkubacji objawy zgnilizny wystąpiły na około $20 \mathrm{~mm}$ tych organów, a 2 dni później gatunek opanował tkanki korzeni na długości około $40 \mathrm{~mm}$, a łodyg na odcinku $35 \mathrm{~mm}$ (rys. 1). Objawy zgnilizny pojawiły się również na blaszkach i ogonkach liściowych, a tempo ich kolonizacji było podobne zarówno po 3 (około $19 \mathrm{~mm}$ ), jak i po 5 dniach (około $39 \mathrm{~mm}$ ) inkubacji (tab. 1). 


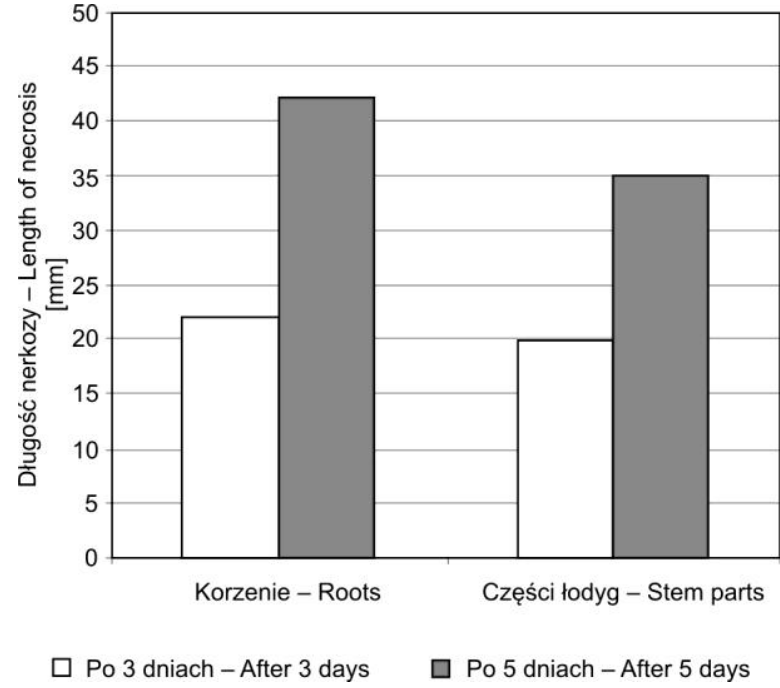

Rys. 1. Kolonizacja korzeni i łodyg dipladenii przez Phytophthora niederhauserii; doświadczenie laboratoryjne

Fig. 1. Colonisation of dipladenia roots and stem parts by Phytophthora niederhauserii; laboratory trial

Tabela 1. Kolonizacja blaszek i ogonków liściowych dipladenii przez Phytophthora niederhauserii; średnica/długość nekrozy [mm]

Table 1. Colonisation of leaf petals and blades by Phytophthora niederhauserii; diameter/length of necrosis [mm]

\begin{tabular}{l|c|c}
\hline \multirow{2}{*}{$\begin{array}{c}\text { Części rośliny } \\
\text { Plant parts }\end{array}$} & \multicolumn{2}{c}{$\begin{array}{c}\text { Dni od inokulacji } \\
\text { Days after inoculation }\end{array}$} \\
\cline { 2 - 3 } & 3 & 5 \\
\hline Blaszki liściowe - Leaf blades & $17,6 \mathrm{a}$ & $37,8 \mathrm{a}$ \\
\hline Ogonki liściowe - Leaf petioles & $19,8 \mathrm{a}$ & $40,0 \mathrm{a}$ \\
\hline
\end{tabular}

Średnie w kolumnach, oznaczone tą samą literą, nie różnią się istotnie $(5 \%)$ wedhug testu Duncana

Means in columns, followed by the same letter, do not differ according to Duncan's multiple range test

W doświadczeniach szklarniowych pierwsze symptomy nekrozy stwierdzono na łodygach i ogonkach liściowych już po 2 dniach od ich inokulacji, a po 4 dniach zgnilizna wystąpiła na około $25 \mathrm{~mm}$ pędu (rys. 2). Po upływie 6 dni omawiany gatunek skolonizował zainokulowane łodygi na długości około $52 \mathrm{~mm}$, podczas gdy ogonki liściowe na długości $48 \mathrm{~mm}$ (rys. 2).

Uzyskane dane wskazują na duże zagrożenie dipladenii przez $P$. niederhauserii, a wywoływane objawy można

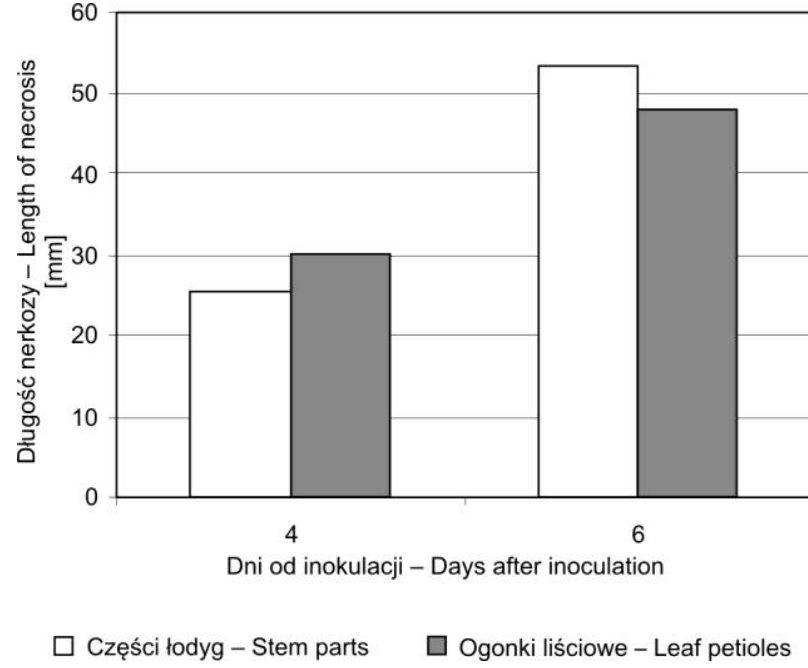

Rys. 2. Kolonizacja części łodyg i ogonków liściowych dipladenii przez Phytophthora niederhauserii w warunkach szklarniowych

Fig. 2. Colonisation of stem parts and leaf petioles of dipladenia by Phytophthora niederhauserii in greenhouse conditions

określić jako zarazę pędów. Stwierdzenie patogenu w obiekcie szklarniowym, gdzie produkuje się tylko rośliny doniczkowe, może stanowić zagrożenie, zwłaszcza gdy zoospory dostaną się do zbiornika z wodą do podlewania lub patogen pozostanie $w$ resztkach podłoża, na parapetach lub przejściach. W innych krajach omawiany czynnik chorobotwórczy izolowano z porażonych korzeni, podstawy pędów i łodyg 33 gatunków roślin należących do 25 rodzin botanicznych począwszy od 2001 roku (Abad i wsp. 2014). Stwierdzono go: w Australii, na Węgrzech, we Włoszech, Izraelu, Japonii, Hiszpanii, Holandii, Norwegii, Wielkiej Brytanii, Turcji, Południowej Afryce, USA i na Taiwanie jako przyczynę: zgnilizny podstawy pędu, chlorozy, zarazy liści, więdnięcia roślin, zrakowaceń i gumozy, szczególnie roślin uprawianych pod osłonami, ale również rosnących w naturalnym środowisku (Abad i wsp. 2014). Wśród żywicieli tego gatunku wyróżnia się zwłaszcza bluszcz (Hedera helix) i czystek szałwiolistny (Cistus salvifolius), ale stwierdzono go również na: banksji, begonii, gloksinii, kalanchoe, migdale, peperomii, winorośli i żywotniku (Herrero i wsp. 2008; Kurbetli i Degirmenci 2011; Abad i wsp. 2014). Niniejsze wyniki są pierwszymi danymi o zagrożeniu dipladenii przez $P$. niederhauserii oraz występowaniu tego gatunku Polsce.

\section{Literatura / References}

Abad Z.G., Abad J.A., Cacciola S.O., Pane A., Faedda R., Moralejo E., Pérez-Sierra A., Abad-Campos P., Alvarez-Bernaola L.A., Bakonyi J., Józsa A., Herrero M.L., Burgess T.I., Cunnington J.H., Smith I.W., Balci Y., Blomquist C., Henricot B., Denton G., Spies C., Mcleod A., Belbahri L., Cooke D., Kageyama K., Uematsu S., Kurbetli I., Degirmenci K. 2014. Phytophthora niederhauserii sp. nov. a polyphagous species associated with ornamentals, fruit trees and native plants in 13 countries. Mycologia 106 (3): 431-437.

Cooke D.E.L., Drenth A., Duncan J.M., Wagels G., Brasier C.M. 2000. A molecular phylogeny of Phytophthora and related oomycetes. Fungal Genetics and Biology 30: 17-32.

Eltlbany N., Zsa-Zsa P., Castaneda-Ojeda M.P., Krogerrecklanfort E., Heuer H., Wohanka W., Ramos C., Smalla K. 2012. A new bacterial disease on Mandevilla sanderi, caused by Pseudomonas savastanoi; lessons learned for bacterial diversity studies. Applied and Environmental Microbiology 78 (23): 8492-8497. 
Herrero M., de Cock A., Klemsdal S., Toppe B. 2008. Phytophthora taxon niederhauserii in greenhouse pot plants in Norway. Journal of Plant Pathology 90 (Suppl. 2), p. 192.

Kurbetli I., Degirmenci K. 2011. First report of Phytophthora taxon niederhauserii causing decline of almond in Turkey. New Disease Reports 23, p. 14.

Orlikowski L.B., Ptaszek M., Trzewik A., Orlikowska T. 2011. Przydatność pułapek liściowych do detekcji Phytophthora spp. z wody. Sylwan 155 (7): 493-499.

Orlikowski L.B., Szkuta G. 2001. Dieback of Pieris japonica caused by Phytophthora citrophthora. Acta Mycologica 36 (2): $251-256$.

Paludan N., Heide M., Begtrup J., Borkhardt B. 1988. Viruses in Diplodenia sanderi. Acta Horticulturae 234: 53-60.

Ruhl G., Twieg E., Devries R., Levy L., Byrne J., Mollov D., Taylor N. 2011. First report of bacterial wilt in Mandevilla (= Dipladenia) splendens "Red Riding Hood" in the United States caused by Ralstonia solanacearum biovar 3. Plant Disease 95 (5), p. 614.

Sella L., Cosmi T., Giacomello F., Saccardi A., Favaron F. 2010. First report of Fusarium oxysporum on Diplodenia sp. in Italy. Journal of Plant Pathology 92 (2), p. 543.

White T.J., Bruns T., Lee S., Taylor J.W. 1990. Amplification and direct sequencing of fungal ribosomal RNA genes for phylogenetics. p. 315-322. In: "PCR Protocols: A Guide_to Methods and Applications" (M.A. Innis, D.H. Gelfand, J.J. Sninsky, T.J. White, eds.). Academic Press, San Diego, California, USA, 482 pp. 